\title{
Strategi Guru Akidah Akhlak dalam Menanamkan Karakter pada Peserta Didik di MTs 1 Woja
}

\author{
Idhar \\ Program Studi Pendidikan Jasmani Kesehatan dan Rekreasi, STKIP Yapis Dompu \\ E-mail: yhunidhar8899@gmail.com
}

Article History: Received: 2022-01-11 || Revised: 2022-02-01 || Published: 2022-02-08

Sejarah Artikel : Diterima: 2022-01-11 || Direvisi: 2022-02-01 || Dipublikasi: 2022-02-08

\begin{abstract}
Research has been carried out on the Strategy of Akhlak Teachers in Instilling Character in Students at MTs 1 Woja. This research is a qualitative research using a descriptive qualitative approach. This research only tries to reveal or describe the facts that exist in MTs 1 Woja. The researcher acts as a key instrument. The data sources used are secondary and primary data sources. The approaches used are: a) pedagogic approach, b) psychological approach, and c) social approach. The results obtained include: Objective conditions regarding the character of students at MTs I Woja in general, students have good character. The visible characters shown by students in the MTs I Woja environment can be concluded as; Students tend to be obedient, polite to all teachers and to fellow students, disciplined, calm and earnest and always maintain harmony and intimacy with others. b) There are several supporting and inhibiting factors for teachers of moral aqidah in instilling character in students at MTs I Woja, and c) Teachers providing guidance through lectures (at school and at home), it is recommended/required to read a lot of things related to religion ( relating to the formation of character for students with problems continue to be given direction so as not to repeat the mistakes they have made, students with problems are handed over to the BK teacher (BP teacher) for guidance.
\end{abstract}

Keywords: Teacher Strategy, Character, Students

\begin{abstract}
Abstrak
Telah dilakukan penelitian tentang Strategi Guru Akidah Akhlak dalam Menanamkan Karakter pada Peserta Didik di MTs 1 Woja. Peneltian ini merupakan penelitian kualitatif dengan menggunakan pendekatan kualitatif deskriptif. Penelitian ini hanya berusaha mengungkapkan atau mendeskripsikan fakta yang ada di MTs 1 Woja. Peneliti bertindak sebagai instrumen kunci. Sumber data yang digunakan adalah sumber data skunder dan primer. Adapun pendekatan yang digunakan, yakni: a) Pendekatan pedagogik, b) Pendekatan psikologi, dan c) Pendekatan sosial. Adapun hasil yang didapatkan diantaranya: Kondisi obyektif tentang karakter peserta didik di MTs I Woja pada umumnya peserta didik memiliki karakter yang baik. Karakter yang dapat dilihat yang ditunjukkan oleh peserta didik di lingkungan MTs I Woja dapat disimpulkan seperti; peserta didik cenderung patuh, sopan terhadap semua guru dan terhadap sesama pesrta didik, disiplin, tenang sungguhsungguh serta senantiasa menjaga keharmonisan dan keakraban terhadap sesama. b) Terdapatnya beberapa faktor pendukung dan penghambat guru akidah akhlak dalam menanamkan karakter pada siswa di MTs I Woja, dan c) Guru memberikan pembinaan melalui ceramah (di sekolah dan di rumah), disarankan/ diharuskan banyak membaca hal-hal yang berkaitan dengan agama (yang berkaitan dengan pembentukan karakter untuk peserta didik yang bermasalah terus diberikan arahan agar tidak mengulangi lagi kesalahan yang pernah mereka perbuat, peserta didik yang bermasalah diserahkan pada guru BK (guru BP) untuk diberi pembinaan.
\end{abstract}

\section{Kata kunci: Strategi Guru, Karakter, Peserta Didik}

\section{PENDAHULUAN}

Tenaga pendidik merupakan tokoh yang utama dalam mendidik dan membina peserta didik di lingkungan sekolah sekaligus menjadi teladan bagi seluruh peserta didik dalam mengembangkan potensi yang dimilikinya, dalam kaitannya dengan ini guru menjadi orang yang sangat penting dalam membina peserta didik agar mereka memiliki karakter yang baik atau "al-akhlak al-karimah" sebagai bekal untuk kehidupannya di masa sekarang dan masa yang akan datang. Khususnya guru 
akidah akhlak harus memiliki strategi pembelajaran yang kuat dan tepat untuk mengarahkan peserta didik dalam membekalinya dengan sikap yang baik, sopan santun, jujur, peduli, bertanggungjawab, dan selalu optimis bahwa peserta didik mampu menghadapi tantangan hidup dan perubahan zaman, serta mereka bisa lebih baik dalam menjalankan hidupnya, dan mampu mencari solusi terhadap segala persoalan yang dihadapi, sejalan dengan ungkapan di atas, Sudarwan Danim (2010), menyatakan bahwa: "guru merupakan pendidik profesional dengan tugas utama mendidik, mengajar, membimbing, mengarahkan, melatih, menilai, dan mengevaluasi peserta didik pada jalur pendidikan formal, tugas utama itu akan efektif jika guru memiliki derajat profesionalitas tertentu yang tercermin dari kompetensi, kemahiran, kecakapan, atau ketrampilan yang memenuhi standar mutu atau norma etik tertentu".

Penjelasan tersebut memberikan pengertian bahwa peran guru sangat penting dalam menanamkan karakter pada peserta didik, agar dalam proses pembelajaran yang dilaksanakan di sekolah menjadi peluang bagi peserta didik untuk memperbaiki diri. Berdasarkan hasil pengamatan penulis ditemukan bahwa karakter peserta didik cenderung patuh, taat, dan hormat pada guru dan terhadap sesama peserta didik. Salah satu aktivitas rutin yang menjadi sarana pembentukan karakter peserta didik adalah melaksanakan salat fardhu secara berjamaah setiap hari pada hari aktif sekolah. Di sini dapat dipahami bahwa kondisi seperti ini tentu tidak terlepas dari strategi serta usaha yang dilakukan oleh guru akidah akhlak dalam menanamkan karakter pada peserta didik, sehingga karakter yang baik yang dimiliki oleh peserta didik itu akan menjadi harapan bagi kelangsungan sekolah di masa mendatang, berkaitan dengan hal tersebut, ada beberapa pandangan yang penulis jadikan dasar, antara lain: Firman Allah SWT dalam Al-Quran surah al-Ahzab/33:21, yang berbunyi:

Terjemahanya:

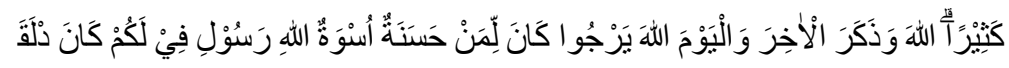

Sesungguhnya pada diri Rasulullah itu telah ada suri teladan bagimu yang baik (yaitu) orang yang mengharap (rahmat) Allah dan kedatangan hari akhir dan banyak mengingat Allah.

Dari ayat tersebut, dapat dipahami bahwa kita harus senantiasa berbuat kebaikan (memiliki karakter yang baik), dan terus diupayakan agar dapat menjadi contoh bagi yang lain, terutama guru yang bertindak selaku pendidik bagi peserta didik. Guru dalam dunia pendidikan adalah seorang pendidik, pelatih dan pengembang kurikulum yang dapat menciptakan kondisi dan suasana belajar yang kondusif, yaitu suasana belajar yang menyenangkan, menarik, memberi rasa aman, memberi ruang pada peserta didik untuk berpikir aktif, dan inovatif dalam mengeksplorasi dan mengelaborasi kemampuannya, sedangkan, menurut Undang-Undang RI No. 14 tahun 2005 tentang Guru dan Dosen menyatakan bahwa guru adalah pendidik profesional dengan tugas utama mendidik, mengajar, membimbing, mengarahkan, melatih, menilai, dan mengevaluasi peserta didik pada pendidikan anak usia dini jalur pendidikan formal, pendidikan dasar, dan pendidikan menengah, menurut Undang-Undang Sistem Pendidikan Nasonal, Pendidik adalah tenaga kependidikan yang berkualifikasi sebagai guru, dosen, konselor, pamong belajar, widyaiswara, tutor, instruktur, fasilitator, dan sebutan lain yang sesuai dengan kekhususannya, serta berpartisipasi dalam menyelenggarakan pendidikan.

Nana Syaodikh Sukmadinata dalam Abuddin Nata menyatakan bahwa mendidik adalah pekerjaan profesional karena itu guru sebagai pelaku utama pendidikan merupakan pendidik profesional. Selanjutnya dalam Undang-Undang Guru dan Dosen ditegaskan secara jelas dalam pasal 2 ayat (1); yang menyatakan bahwa guru mempunyai kedudukan sebagai tenaga profesional pada jenjang pendidikan dasar, pendidikan menengah, dan pendidikan usia dini pada jalur pendidikan formal yang diangkat sesuai dengan peraturan perundang- undangan. Melihat makna 
guru di atas, dapat dipahami bahwa seorang guru bukan hanya sekedar pemberi ilmu (transfer of knowledge) pengetahuan saja yang berada di depan kelas, akan tetapi guru merupakan tenaga profesional yang dapat menjadikan murid-muridnya mampu merencanakan, menganalisis, dan menyelesaikan masalah yang dihadapi.

Predikat sebagai tenaga profesional melekat pada penyandang profesi tertentu. Hal tersebut dapat dipahami dari pandangan yang dikutip oleh Sudarwan dan Khairil dalam Donald L Mills dan Howard M.Vollmer menyatakan bahwa profesi adalah sebuah jabatan yang memerlukan tingkat intelektual khusus, yang diperoleh melalui kegiatan belajar dan pelatihan yang bertujuan untuk menguasai keterampilan atau keahlian dalam melayani atau memberikan advis pada orang lain, dengan memeroleh upah atau gaji dalam jumlah tertentu. Dengan demikian guru harus memiliki dan menguasai beberapa strategi untuk memberikan pembinaan sebagai sarana menanamkan karakter pada peserta didik.

\section{METODE PENELITIAN}

Jenis penelitian yang digunakan dalam peneltian ini adalah penelitian kualitatif dengan mengguanakan pendekatan deskriptif. Penelitian ini hanya berusaha mengungkapkan atau mendeskripsikan fakta di lapangan dengan apa adanya. Secara istilah penelitian kualitatif sebagaimana pendapat yang diungkapkan Sugiono (dalam Ekha dan Taufik, 2020) menyebutkan, pendekatan kualitatif sebagai pendekatan yang digunakan untuk meneliti objek yang alamiah (sebagai lawan dari eksperimen), Instrumen yang digunakan dalam penelitian ini adalah peneliti sendiri, karena peneliti bertindak sebagai instrumen kunci. Sumber data yang digunakan dalam peneltian ini adalah sumber data skunder dan primer. Adapun pendekatan yang digunakan dalam penelitian ini diantaranya: a) Pendekatan pedagogik, b) Pendekatan psikologi, dan c) Pendekatan sosial.

\section{HASIL DAN PEMBAHASAN}

\section{A. Kondisi Objektif Karakter Peserta Didik di MTs I Woja}

Berdasarkan pengamatan yang dilakukan selama di lapangan kondisi obyektif karakter peserta didik di MTs I Woja dapat dikategorikan sebagai karakter yang baik. Hal ini dilihat dari mulai kedatangan peserta didik pada jam masuk sekolah, sikap mereka selama berada di lingkungan sekolah, keaktifan mereka mengikuti proses pembelajaran yang berlangsung, dan kepatuhan mereka terhadap semua aturan sekolah serta hormat dan taat pada semua guru (pendidik). Hal tersebut menjadi indikato atu tolok ukur bahwa karakter peserta didik dikategorikan baik. Dalam hal pembentukan karakter peserta didik, mereka setiap hari pada pukul 07:15 menit setiap hari senin mereka sudah hadir di sekolah untuk mengikuti upacara pagi. Selanjutnya, mengikuti proses pembelajaran yang berlangsung sampai pada pukul pada pukul 12.00 dan tepat pada pukul 12:00 semua proses pembelajaran dihentikan, dan semua peserta didik diarahkan ke mesjid untuk mengikuti pelaksanaan salat zduhur secara berjamaah. Sepuluh menit sebelum pelaksanaan salat semua peserta didik sudah selesai ambil air wudhu (dapat dipastikan sudah siap pada posisi teratur), setelah itu kemudian mereka diarahkan untuk menempati posisi masing-masing secara bersaf pertanda salat berjamaah segera dilaksanakan.

Berkaitan pelaksanaan salat berjamaah mereka tidak diawasi lagi oleh guru akidah akhlak ataupun guru yang lain, karena mereka dididik untuk tertib dan disiplin apabila berada dalam mesjid. Selesai melaksanakan salat berjamaah secara bersama, mereka langsung masuk kembali ke ruangan kelas masing-masing untuk melanjutkan atau mengikuti pembelajaran. Khusus pada hari sabtu setelah mereka melakukan salat berjamaah, mereka diwajibkan untuk mengaji atau membaca Al-Quran secra bersama-sama. Selesai membaca Al-Quran selama 20 menit, mereka kembali ke ruangan mengikuti pembelajaran, dan mereka pulang pada pukul 14:00 (jam 02). Hal 
tersebut dapat dilihat di lapangan (di lingkungan sekolah) pada setiap hari aktivitas sekolah berlangsung, baik dalam ruangan ketika pembelajaran sedang berlangsung maupun di luar ruangan kelas. Suasana karakter yang tampak dimiliki oleh peserta didik tersebut setiap harinya berjalan dengan tertib dan sanagat disiplin sebagaimana yang diinginkan di sekolah tersebut. Karakter peserta didik yang baik tersebut terlihat pada sikap mereka pada semua guru, pada sesama peserta didik, dan terhadap lingkungan mereka di sekolah.

Setiap pagi mereka datang ke sekolah dengan suasana tenang, sopan terhadap sesama itu senantiasa mengiringi keseharian mereka ketika datang menuntut ilmu di sekolah sebagai bagian dari proses pembelajaran. Mereka setiap harinya mendapat pendidikan di sekolah sebagai bekal dalam memperbaiki karakter. Kesempatan ini tidak disia-siakan oleh peserta didik karena mereka mengannggap bahwa masa sekolah merupakan kesempatan terbaik untuk membenahi diri dengan karakter yang baik. Karakter yang mereka tunjukkan seperti sikap peduli terhadap sesama, sopan, keakraban, bertanggungjawab terhadap diri sendiri terutama yang berkaitan dengan tugas mereka sebagai peserta didik, bermain bersama (tanpa membedakan apakah dia dari keluarga kaya ataupun dari keluarga sederhana), dan senantiasa berusaha menjauhi sikap suka tawuran antar pelajar. Jadi, karakter yang dapat dilihat yang ditunjukkan oleh peserta didik di lingkungan MTs 1 Woja cenderung patuh, sopan, disiplin, tenang (tidak membuat keributan), sungguh-sungguh (serius mengikuti pembelajaran), serta senantiasa menjaga keharmonisan dan keakraban terhadap sesama.

B. Faktor Pendukung dan Penghambat Guru Akidah Akhlak dalam Menanamkan Karakter Pada Siswa di MTs I Woja

Sebagai salah satu tanggungjawab sebagai guru akidah akhlak dalam hal mendidik peserta didik supaya mereka memiliki karakter yang baik, tidak selamanya dalam pelaksanaannya guru tersebut sering menemui hal-hal yang menjadi kendala. Ada beberapa hal yang mendukung mapun hal-hal yang menjadi penghambat dalam melakukan pembinaan karakter pada peserta didik.

\section{Faktor Pendukung}

Beberapa hal yang menjadi faktor pendukung guru akidah akhlak dalam menanamkan karakter pada peserta didik di MTs 1 Woja sebagai berikut:

a) Kepala sekolah

Sebagai kepala madrasah, dengan wewenang yang dimiliki dia senantiasa mengontrol dan memberi motivasi pada semua pendidik maupun peserta didik di MTs 1 Woja supaya penanaman dan pembentukan karakter yang baik pada peserta didik terus ditingkatkan.

b) Guru (pendidik)

Proses pembentukan karakter peserta didik di lingkungan sekolah sangat ditentukan oleh usaha yang dilakukan oleh pendidik, sebab yang bertanggungjawab penuh selama peserta didik berada di lingkungan sekolah adalah pendidik. Dengan demikian pendidik memiliki tanggungjawab yang besar terhadap perkembangan karakter peserta didik.

c) Orang tua

Untuk membantu pembentukan karakter pada peserta didik peran orang tua sangat penting dalam pembentukan karakter pada anak. Orang tua memiliki waktu yang banyak ketimbang pendidik di sekolah untuk mendidik anak mereka agar anak tersebut memiliki dasar karakter yang baik, sehingga pendidik tida kesulitan dalam menanamkan karakter pada peserta didik.

d) Faktor lingkungan

Dalam hal ini lingkungan masyarakat juga sangat berpengaruh terhadap pembentukan sikap peserta didik. Hal yang berpengaruh di sini yaitu sahabatnya (lingkungan pergaulan). 
Apabila lingkungan tempat mereka bergaul/bermain itu baik, berarti lingkungan tersebut dapat memberi perkembangan yang positif terhadap seorang anak. Jika sebaliknya lingkungan yang mereka tempai bergaul itu lebih dominan hal negatif, dapat dipastikan bahwa sikap/karakter seorang anak tersebut akan dipengaruhi oleh sikap yang negatif.

\section{Faktor Penghambat}

Kehidupan manusi tidak pernah terlepas dari peroalan yang senaniasa mengiringi kehidupanya, baik kehidupan kelurga, maupun kehidupan bermasyarakat, untuk memberikan pembinaan terhadap karakter peserta didik terdapat beberapa faktor yang menjadi penghambat.

a) Orang tua

Orang tua yang kurang memerhatikan perkembangan karakter seorang anak, ini menjadi salah satu faktor utama sebagai penyebab perkembangan karakter yang tidak baik pada anak. Lemahnya pengawasan dari orang tuanya seorang anak bisa saja karakternya tidak sesuai dengan apa yang diharapkan, sejak kecil atau muali dari masa kanak-kanak seoarang anak tentu sangat dekat dengan orang tuanya, maka perilaku orang tua ataupun orang sekitarnya juga dapat ditiru oleh anaknya. Orang tua dalam lingkungan rumah tangga diharapkan mampu membina anaknya menjadi lebih baik dan memberikan contoh akhlak yang mulia sebagaimana akhlaknya Rasulullah SAW sebagai teladan yang patut dicontohi.

b) Lingkungan masyarakat.

Tanggung jawab masyarakat terhadap pendidikan anak-anak adalah membiasakan perilaku yang baik dalam kehidupan sosial sebagai bentuk pendidikan dalam kehidupan bermasyarakat. Terkadang yang dapat dilihat pada anak ada perkembangan sikap yang kurang baik pada diri seorang anak, kemungkinan sikap tersebut tanpa mereka sadari adalah sikap yang didapat ketika mereka bergaul dengan teman-temanya di lingkungan masyarakat. Sikap yang dimaksud sepert; adanya watak yang keras pada diri anak, tidak kreatif (senang pada yang serba instan), semangat belajar kurang (cepat bosan). Hal demikian bisa jadi diperolehnya terhadap lingkungan yang kurang baik dalam pergaulannya.

c) Teknologi

Perkembangan teknologi di masa kini memberi pengaruh besar terhadap perubahan sikap bagi peserta didik, baik sikap yang positif maupun sikap yang negatif. Bagi peserta didik yang mampu memanfaatkan teknologi dengan baik, maka teknologi tersebut sangat bermanfaat bagi perkembangan ilmu pengetahuannya, kreativitas, dan mendapatkan informasi untuk pengembangan hidup bagi mereka. Sebaliknya teknologi dapat memberi efek atau pengaruh yang buruk terhadap perkembangan karakter peserta didik, apabila penggunaan teknologi tersebut mereka tidak mampu menggunakan untuk perkembangan yang positif bagi mereka.

C. Upaya dan Solusi Guru Akidah Akhlak Mengatasi Faktor Penghambat dalam Menanamkan Karakter Pada Siswa di Mts 1 Woja

Berbagai upaya dan solusi senantiasa dilakukan untuk meminimalisir terjadinya hal-hal yang menghambat pada pembentukan karakter peserta didik sebagai wujud dari proses pembelajaran yang telah dilakukan di dalam ruang kelas. Guru akidah akhlak dalam hal ini Muhammad Hasyim, dia menyatakan bahwa sebagai solusi yang dilakukan untuk mengatsi faktor penghambat dalam menanamkan karakter pada peserta didik saat ini adalah: 
1. Memberikan pembinaan melalui ceramah (di sekolah dan di rumah).

2. Disarankan/diharuskan banyak membaca hal-hal yang berkaitan dengan agama (yang berkaitan dengan pembentukan karakter (akhlak)).

Selain penjelasan dari Muhammad Hasyim di atas, Nur Rahmah Asnawi selaku guru akidah akhlak juga, dia menyatakan bahwa dalam menghadapi peserta didik kita harus memahami bahwa mereka memiliki karakter berbeda-beda (misalnya ada peserta didik yang bermasalah), sehingga solusi yang dilakukan berbeda, diantaranya:

1. Untuk peserta didik yang bermasalah terus diberikan arahan agar tidak mengulangi lagi kesalahan yang pernah mereka buat.

2. Peserta didik yang bermasalah diserahkan pada guru BK (guru BP) untuk diberi pembinaan.

Pendapat yang lain disampaikan oleh Andi Achruh AB. Pasinringi, selaku kepala sekolah dia menyatakan bahwa sebagai solusi yang dilakukan untuk mengatasi peserta didik dalam pembentukan karakter adalah: Menanamkan karakter (akhlak) yang baik pada diri peserta didik, sehingga diharapkan ke depannya peserta didik dapat memiliki karakter atau sikap yang baik untuk menjadi pribadi yang berguna, baik bagi dirinya, keluarganya, maupun berguna bagi lingkungan sosial (lingkungan masyarakat), dari penjelasan tersebut, dapat dipahami bahwa sebagai solusi yang harus dilakukan oleh guru akidah akhlak dalam menanamkan karakter pada peerta didik adalah harus dilakukan pembinaan akhlak yang mulia sejak dini di lingkungan sekolah sehingga dapat bermanfaat bagi dirinya maupun orang lain di lingkungan masyarakat tempat peserta didik itu berada.

\section{SIMPULAN DAN SARAN}

\section{A. Simpulan}

Berdasarkan penjelasan dan hasil penelitian serta data-data yang telah disajikan di atas, maka disimpulkan intisari dari pembahasan tersebut yaitu sebagai berikut:

1. Kondisi obyektif tentang karakter peserta didik di MTs I Woja pada umumnya peserta didik memiliki karakter yang baik. Karakter yang dapat dilihat yang ditunjukkan oleh peserta didik di lingkungan MTs I Woja dapat disimpulkan seperti; peserta didik cenderung patuh, sopan terhadap semua guru dan terhadap sesama pesrta didik, disiplin, tenang (tidak membuat keributan), sungguh-sungguh (serius mengikuti pembelajaran), serta senantiasa menjaga keharmonisan dan keakraban terhadap sesama. Karakter tersebut terlihat dalam hal disiplin mulai dari kedatangan sekolah (tepat waktu pada jam masuk sekolah), sikap mereka selama berada di lingkungan sekolah, keaktifan mereka mengikuti proses pembelajaran yang berlangsung, dan kepatuhan mereka terhadap semua aturan sekolah serta hormat dan taat pada semua guru (pendidik).

2. Faktor pendukung dan penghambat guru akidah akhlak dalam menanamkan karakter pada siswa (peserta didik) di MTs I Woja adalah sebagai beriku: a) faktor pendukung yaitu; (1) kebijakan kepala madrasah, (2) kesungguhan para guru, (3) keterlibatan orang tua, dan (4) faktor lingkungan. Sedangkan b) faktor penghambat yaitu; (1) kurangnya perhatian orang tua, (2) kurangnya perhatian sebagian guru, (3) pengaruh lingkungan yang tidak baik, dan (4) pengaruh teknologi.

3. Memberikan pembinaan melalui ceramah (di sekolah dan di rumah), disarankan/diharuskan banyak membaca hal-hal yang berkaitan dengan agama (yang berkaitan dengan pembentukan karakter (akhlak)), untuk peserta didik yang bermasalah terus diberikan arahan agar tidak mengulangi lagi kesalahan yang pernah mereka perbuat, peserta didik yang bermasalah diserahkan pada guru BK (guru BP) untuk diberi pembinaan, srta menanamkan karakter (akhlak) yang baik pada diri peserta didik sehingga diharapkan kedepannya peserta didik dapat 
memiliki karakter atau sikap yang baik untuk menjadi pribadi yang berguna baik bagi dirinya, keluarganya, maupun berguna bagi lingkungan sosial (lingkungan masyarakat).

\section{B. Saran}

Hasil penelitian ini diharapkan dapat dimanfaatkan sebagai tambahan pengetahuan dalam pendidikan karakter keagamaan, sehingga dapat memberikan efek yang lebih baik kedepanya dalam proses belajar mengajar, khusunya pada kepada guru akidah akhlak agar terus mengupayakan penanaman karakter pada peserta didik dengan menggunakan berbagai strategi, langkahlangkah, metode, dan pendekatan yang tepat sehinngga dapat mewujudkan peserta didik yang memiliki karakter yang baik atau peserta didik yang ber-akhlak al-karimah yang berguna bagi dirinya, masyarakat, maupun bagi bangsa dan negara.

\section{DAFTAR RUJUKAN}

Abudin Nata. 2003. Manajemen pendidikan:mengatasi kelemahan pendidikanIslam di Indonesia. Jakarta: Media Kencana Grup

Arifin, A., Sugerman, S., \& Amin, M. (2021). Respon Guru Tentang Pelanggaran yang dilakukan Siswa (Studi Kasus di SDN 10 Pajo). Ainara Journal (Jurnal Penelitian Dan PKM Bidang Ilmu Pendidikan), 2(3), 193-205. https://doi.org/10.54371/ainj.v2i3.81

Arikunto, S. (2013). Prosedur Penelitian Suatu Pendekatan Praktik. Jakarta: Rinneka Cipta.

Danim, Sudarwan. (2010). Perkembangan Peserta Didik. Bandung: Alfabeta

Http://luk.staff.ugm.ac.id/atur/UU14-2005GuruDosen.pdf

Https://tafsiralquran.id/tafsir-surat-al-ahzab-ayat-21-nabi-muhammad-saw-adalah-suri-tauladan/

Ridwan. (2009). Belajar Mudah Penelitian Untuk Guru-Karyawan dan Peneliti Pemula. Bandung: Alfabeta.

Sugiyono. (2013). Metode Penelitian Pendidikan. Bandung: Alfabeta.

Taufik, Erwin, \& Husnul Khatimah. (2020). Pengembangan Perangkat Pembelajaran Model CIRC pada Mata Kuliah Apresiasi Sastra "Mantra Mbojo" untuk Melatih Kemampuan Berpikir Kreatif Mahasiswa.JIIP - Jurnal Ilmiah Ilmu Pendidikan,3(3), 635-641. Retrieved from http://jiip.stkipyapisdompu.ac.id/jiip/index.php/JIIP/article/view/171

Taufik, T., Imansyah, M. N., \& Yulianti, E. (2021). Efektivitas Penggunaan Buku Ajar Sastra Lisan Suku Mbojo Berorientasi pada Model CIRC untuk Matakuliah Apresiasi Sastra. Jurnal Inovasi, Evaluasi Dan Pengembangan Pembelajaran (JIEPP), 1(2), 41-45. https://doi.org/10.54371/jiepp.v1i2.104

Yulianti, E., \& Taufik, T. (2020). Studi Perbandingan Eksistensi Alam Pada Novel Tanah Baru Tanah Air Kedua Karya Nh. Dini Dan Sri Rinjani Karya Eva Nourma (Tinjauan Ekologi Sastra). Ainara Journal (Jurnal Penelitian Dan PKM Bidang Ilmu Pendidikan), 1(2), 44-55. https://doi.org/10.54371/ainj.v1i2.13

Yusnarti, M., \& Suryaningsih, L. (2021). Pengaruh Model Pembelajaran Role Playing Terhadap Hasil Belajar Siswa Sekolah Dasar. Ainara Journal (Jurnal Penelitian Dan PKM Bidang Ilmu Pendidikan), 2(3), 253-261. https://doi.org/10.54371/ainj.v2i3.89 